\title{
Pelatihan Pemanfaatan Sampah Menjadi Kompos Bagi Mahasiswa STT Real Batam
}

\author{
Fredy Simanjuntak ${ }^{*}$, Ya'aman Gulo ${ }^{2}$, Alfredo Manurung ${ }^{3}$, George Samaran ${ }^{4}$, \\ Oferianus Bulolo ${ }^{5}$, Soraya Sara Kawai ${ }^{6}$, Elda Br. Situmorang ${ }^{7}$ \\ 1, 4, 6 Prodi Teologi, STT REAL Batam \\ 2, 3, 7 Prodi PAK, STT REAL Batam \\ *fredygrace@gmail.com
}

\begin{abstract}
This study aims to determine the extent to which training on the use of waste into compost for STT REAL Batam students.This study also provides an insight into the important role of society in maintaining environmental cleanliness and how to manage and utilize waste that has been thrown away into compost or fertilizer that can be used for agricultural needs and other things. So that the Indonesian nation becomes a country that can keep the environment clean from waste pollution, both plastic waste and non-plastic waste. By using a qualitative analysis method and collecting data based on case studies and interviews so that it will be formulated in the form of written data, data which includes training on the use of waste into compost so that based on these results, it can be concluded that training on the use of waste into compost can be done as a side job, which does not require large capital, but requires the involvement of STT Real Batam students in utilizing organic waste into compost. Therefore, this research can be reviewed so that it becomes a strategy formulation that must be improved for extracurricular development and student competence at STT REAL Batam.
\end{abstract}

Keywords: training, garbage, compost, students

Abstrak
Penelitian ini bertujuan mengetahui sejauh, mana pelatihan pemanfaatan sampah menjadi kompos bagi mahasiswa STT REAL Batam. Penelitian ini juga memberikan pandangan akan peran penting masyarakat dalam menjaga kebersihan lingkungan dan bagaimana mengelolah dan memanfaatkan sampah yang sudah di buang menjadi sebuah kompos atau pupuk yang dapat di gunakan untuk kebutuhan pertanian dan hal lainya. Sehingga bangsa Indonesia menjadi negara yang dapat menjaga kebersihan lingkungan dari pencemaran sampah baik itu sampah plastic-maupun sampah non plastic.Dengan mengunakan metode analisis kualitatif dan mengumpulkan data berdasarkan study kasus dan wawancara sehingga akan dirumuskan dalam bentuk data tulisan,data yang mencakup tentang pelatihan pemanfaatan sampah menjadi kompos sehingga Berdasarkan hasil itu, dapat di simpulkan bahwa pelatihan pemanfaatan sampah menjadi kompos dapat dilakukan sebagai sambilan pekerjaan, yang tidak memerlukan modal yang besar, namun memerlukan keterlibatan mahasiswa STT Real Batam dalam memanfaatkan sampah organic menjadi kompos oleh sebab itu Dengan penelitian ini dapat di tinjau sehingga menjadi rumusan strategi yang harus ditingkatkan untuk pengembangan ekstrakulikuler dan kompetensi mahasiswa yang ada di STT REAL Batam.

Kata kunci: pelatihan, sampah, kompos, mahasiswa

\section{PENDAHULUAN}

Untuk mencapai kondisi masyarakat yang hidup sehat dan sejahtera di masa yang akan dating, maka akan sangat diperlukan adanya lingkungan permukiman yang sehat. Dari aspek persampahan, maka kata sehat akan berarti sebagai kondisi yang akan dapat di capai bila sampah dapat di Kelola secara baik sehingga kebersihan lingkungan permukiman dimana manusia tinggal dan beraktivitas di dalamnya. Sampah merupakan sisa dari kegiatan sehari hari manusia atau proses alam yang berbentuk padat atau semi padat berupa zat organik atau organik bersifat dapat terurai atau tidak. Dapat terurai yang di anggap sudah tidak berguna lagi dan di buang ke lingkungan.

Sampah seringkali menjadi fenomena masalah yang belum bisa di selesaikan secara efektif. Oleh karena itu berbagai strategi sudah dilakukan baik oleh pemerintah maupun Lembaga dan para pegiat lainnya. Kesadaran masyarakat yang masih rendah untuk mengelola sampah menjadi satu pemicu bagi mahasiswa STT Real Batam untuk mengikuti pelatihan pemanfaatan sampah menjadi 
kompos lalu mensosialisasikan kepada masyarakat untuk dapat mengelola dan memanfaatkan sampah sebagai salah satu persoalan yang besar yang selalu menjadi alasan munculnya dampak dari sampah. Sementara itu, sampah baru selalu di hasilkan oleh masyarakat dalam kehidupan kesehariannya. ${ }^{1}$ Pada beberapa daerah tertentu sudah menginisiasi pengolahan sampah, melalui TPA dan pembuatan "bank Sampah" untuk memanfaatkan sampah yang telah di buag dan di Kelola untuk menjadi sebuah bahan kompos yang dapat di gunakan,namun sebelum itu akan di kelolah oleh masyarakat dan mahasiswa STT Real Batam dalam mengelolah sampah yang ada di lingkungannya dan lingkunga,masyarakat lainnya , hal ini di lakukan karena masih seringkali menimbulkan persoalan dalam proses pengolahan dan pemanfaatan sampah,oleh karena itu masyarakat dan mahasiswa STT Real Batam memisahkan sampah organic dan anorganik, untuk di Kelola secara terpisah. Sampah organik dan sampah anorganik harus di pisahkan karena dalam pengolahannya memiliki proses yang berbeda.

Sampah organik sering kali di temui dalam bentuk palstik, kaleng, karet, seng, logam, besi dan bahan organik lainnya, dapat di daur ulang untuk menjadi sebuah barang yang baru lagi. Bahkan pada beberapa daerah yang ada di Indonesia sudah dapat menghasilkan barang kerajinan yang di buat dari bahan-bahan yang naturalnya adalah sampah anorganik. Sementara itu untuk sampah organik seperti daun gugur, sampah dari sisa pertanian, sampah dari sayuran dapur, dan jenis sampah organik lainnya. Dapat di olah untuk di jadikan sebagai pupuk kompos hal inilah yang di lakukan oleh mahasiswa STT Real Batam dalam tugas pengabdian kepada masyarakat dengan mengfungsikan serta mengelola sampah menjadi kompos untuk dapat di gunakan oleh masyarakat dengan demikian maka setiap limbah sampah yang di buang dapat di dayagunakan untuk hal positif bukan saja hanya sebagai tumpukan-tumpukan atau timbunan plastik dan lainnya yang hanya berguna untuk mencemari lingkungan. Dalam pelatihan pemanfaatan pengelolaan sampah ini mahasiswa berharap dan memberikan manfaat yang lebih kepada masyarakat dan juga Lembaga-lembaga terkait di dalamnya untuk mulai memperhatikan kondisi serta kebersihan lingkungan di mana masyarakat itu ada dan bernaung di dalamnya mahasiswa STT Real Batam berharap bahwa melalui pelatihan pengelolaan sampah menjadi kompos akan memberikan dampak yang positif bagi lingkungan kampus dan juga dapat membantu pemerintah untuk mengurangi terjadi nya pencemaran lingkunggan di wilayah kota batam khususnya selain dari pada itu pupuk kompos yang telah di olah menjadi kompos juga dapat di gunakan untuk pertanian atau pemeliharaan tanaman oleh mahasiswa. Pupuk kompos sendiri juga memiliki nilai ekonomis dan peluang usaha yang dapat di kembangkan menjadi sebuah nilai tambah yang didapatkan dari pelatihan pengelolaan sampah sampah organik menjadi pupuk kompos. ${ }^{2}$ Pupuk kompos yang dikelola dari bahan sampah organik juga dapat di gunakan untuk perawatan tanaman dalam system pertanian organi dalam skala rumah tangga dengan menggunakan metode Takakura.

Pelaksanaan tugas dari pada tridarma perguruan tinggi bukan hanya berlaku untuk dosen atau mahasiswa saja dalam melaksanakan kegiatan Pendidikan dan penelitian saja akan tetapi juga melaksanakan tugas lainnya yaitu melakukan pengabdian kepada masyarakat. Oleh karena itu pengabdian kepada masyarakat di pandang sangat perlu untuk di laksanakan dan dilakukan sebagai sarana yang diaplikasikan oleh mahasiswa untuk mendatangkan manfaat bagi masyarakat umum. Upaya dalam pengabdian kepada masyarakat maka mahasiswa STT Real Batam yang tergabung dalam program studi PAK dan Theology berusaha untuk mengambil bagian yang penting yang di perlukan oleh masyarakat yaitu pengelolaan, pemanfaatan dan pengolahan sampah organik menjadi kompos berdasarkan metode sederhana yang di pakai untuk sebuah tujuan dalam meningkatkan nilai manfaat sampah menjadi bahan yang lebih berguna dan hal ini dapat mengurangi pencermran terhadap lingkungan. Oleh sebab itu hal ini di pandang baikoleh mahasiswa STT Real Batam untuk melakukan pemanfaatan pengolahan sampah menjadi kompos serta memberikan sosialisasi bagi masyarakat untuk dapat memperhatikan kebersihan lingkungan dan mulai memberdayakan ilmu yang di dapat pada pelatihan pemanfaatan pengolahan sampah menjadi kompos dengan cara yang sederhana dan mudah untuk di pahami dan dapat diterapkan baik oleh mahasiswa maupun oleh masyarakat. Yang di kemas dalam sebuah paket yang di sebut dengan paket pengabdian kepada masyarakat oleh tim dari

1 Bambang Yuniarto, Membangun Kesadaran Warga Negara Dalam Pelestarian Lingkungan (Yogyakarta: CV Budiman Utama, 2018).hal. 100.

2 Sri Wahyuni,dkk "Pelatihan Pengolahan Sampah Organik Skala Rumah Tangga Dengan Metode Takakura Di Desa Gebung," Indonesia Journal of Cummunity empowement 1161, no. 2657-117 (2019): hal. 53. 
Mahasiswa STT Real Batam yang bekerja sama dengan lembaga -lembaga yang ikut serta berperan dalam pengolahan pemanfaatan sampah menjadi kompos.

Adapun tujuan dilaksanakanya kegiatan pelatihan pemanfaatan pengolahan sampah menjadi kompos ini sebagai kegiatan pengabdian masyarakat adalah. (1) mengsosialisasikan bahwa kebersihan lingkungan merupakan hal yang sangat penting dan mengajak setiap lapisan masyarakat dapat membuang sampah pada tempat sampah yang telah disediakan (2). Menerangkan tentang jenis-jenis sampah yang akan di buang supaya sebelum sampah tersebut di buang di tong atau bak sampah dapat di pilah untuk di daur ulang atau di jadikan sebagai pupuk organi. (3). Memberikan nilai jual terhadap sampah organic agar dapat berdaya guna, dengan cara mengolahnya menjadi pupuk kompos. (4) menjelaskan serta mendampingi setiap orang yang ikut terlibat dalam kegiatan pengabdian masyarakat yaitu pemanfaatan pengolahan sampah menjadi pupuk kompos di lokasi di mana kegiatan tersebut berlangsung. Dalam program kegiatan ini pengabdian masyarakat ini di harapkan dapat meningkatkan masyarakat bahkan mahasiswa khususnya untuk Bersama-sama menjaga kebersihan lingkungan agar dengan demikian kegiatan yang di lakukan ini dapat meningkatkan pengetahuan mahasiswa dan masyarakat bahwa sampah mempunyai manfaat untuk dapat di kelola dengan baik sehingga dapat menjadi nilai jual yang dapat di pergunakan untuk kebuhan hidup contohnya pupuk kompos yang berfungsi untuk menjadi nutrisi bagi tanaman dan hal lainnya.

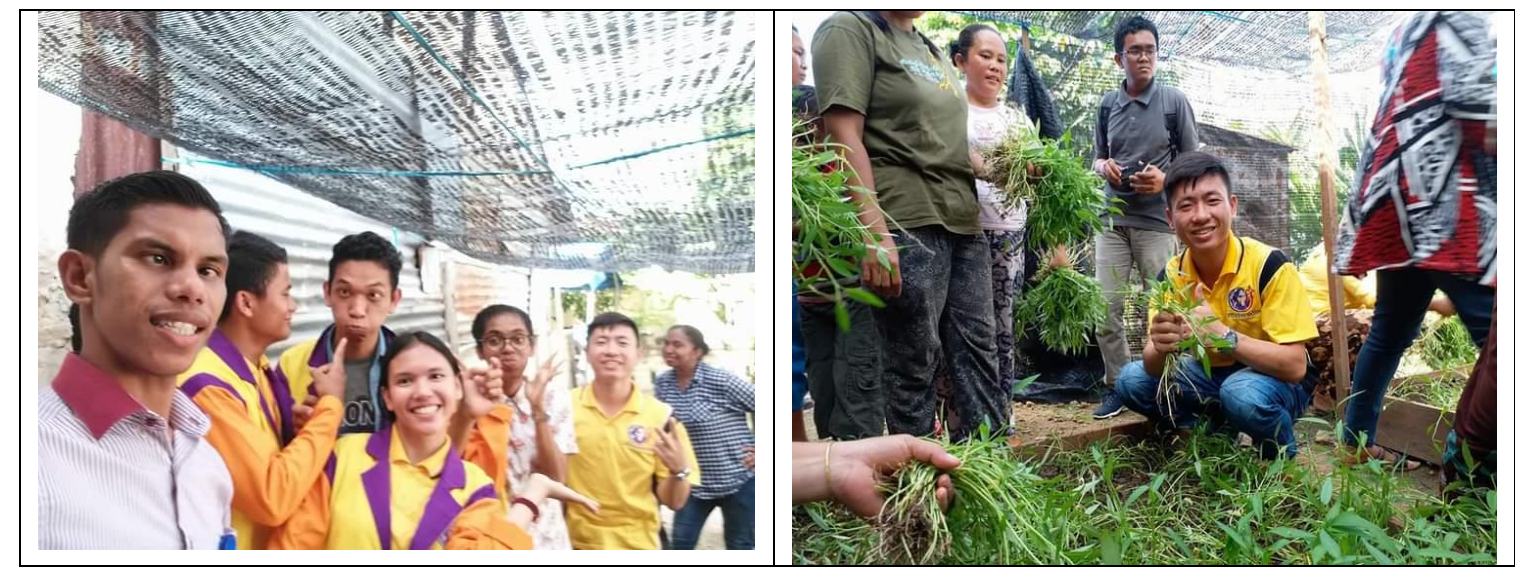

Gambar 1. Tim Komposter Mahasiswa Berada Di Lokasi Komposter

\section{METODE}

Penelitian ini dilakukan oleh penulis dengan mengunakkan metode Deskripsi kualitatif dimana penelitian ini menganalisis data, mengumpulkan data, melalui pengamatan dan observasi serta mengintepresi data dan merumuskan serta mengevaluasi hasil kegiatan dan memberikan kesimpulan yang mengacu pada analisis data tersebut. Adapun tujuan dari penelitian ini adalah untuk mengungkapkan kejadian atau fakta, keadaan, fenomena, variabel dan keadaan yang terjadi saat penelitian berlangsung dengan menyuguhkan apa yang sebenarnya terjadi. Penelitian ini menafsirkan dan menguraikan data yang bersangkutan dengan situasi yang sedang terjadi, sikap serta pandangan yang terjadi di dalam suatu masyarakat hubungan antar variable yang timbul, perbedaan antar fakta yang ada serta pengaruhnya terhadap suatu kondisi mengenai palatihan pemanfaatan sampah menjadi kompos bagi mahasiswa STT Real Batam. Kegiatan Komposter ini melibatkan beberapa Mahasiswa yaitu, George, Oferianus, Elda, Alfredo, Ya'aman dan. Kegiatan dilakukan pada Tanggal 10 Mei-10 Juni 2018 di wilayah RT 001/RW 020 kelurahan kabil, kecamatan nongsa, Batam Kepulauan Riau

\section{HASIL DAN PEMBAHASAN}

Sampah adalah bagian tak terpisahkan dalam keseharian kita. Sejak lahirpun kita telah menjadi produsen sampah dan terus menghasilkan sampah di sepanjang perjalanan hidup. Dewasa ini sampah telah merupakan masalah urgen yang perlu ditangani pemerintah terutama dalam memelihara kelestarian dan kesehatan lingkungan.Sampah dihasilkan di rumah, kantor, pasar, terminal, pelabuhan, 
jalan dan di mana-mana. ${ }^{3}$ Oleh sebab itu diperingati Acara peringatan Hari Peduli Sampah Nasional 2016 di Bundaraan HI, Jakarta, Minggu (21/2). Indonesia Bebas Sampah tahun 2020. ${ }^{4}$ Sehingga Sebelum diadakan kegiatan pelatihan pemanfaatan sampah menjadi kompos dari sampah sisa kegiatan baik itu dipasar dan lingkungan perumahan maka hal ini menimbulkan beberapa permasalahan di antaranya lingkungan yang kotor, bau yang tidak sedap, serta banyak kuman penyakit yang bertebaran. Namun setelah kegiatan pelatihan pemanfaatan sampah menjadi kompos masyarakat dan mahasiswa mulai memiliki kesadaran untuk membuang sampah pada tempatnya. Sampah yang akan di buang sebelumnya mulai dipilah berdasarkan jenisnya,yaitu sampah organic dan anorganik. ${ }^{5}$ Selanjutnya selama pelatihan berlangsung mahasiswa juga mendapatkan pengetahuan yang baru bahwa sampah organic dari sisa kegiatan masyarakata baik di rumah atau di pasar dapat diolah menjadi sesuatu yang punya nilai jual yaitu pupuk kompos dalam skala kecil namun memberikan manfaat yang baik bagi masyarakat dan mahasiswa sendiri dengan demikian sampah yang dapat dikelola dengan baik tidak terbuang sia-sia.Oleh karena itu Sampah merupakan persoalan yang harus ditanggulangi mengingat dampaknya yang berbahaya bagi kesehatan dan lingkungan. Seluruh lapisan masyarakat baik di desa maupun di kota akan selalu bersinggungan dengan hal ini.

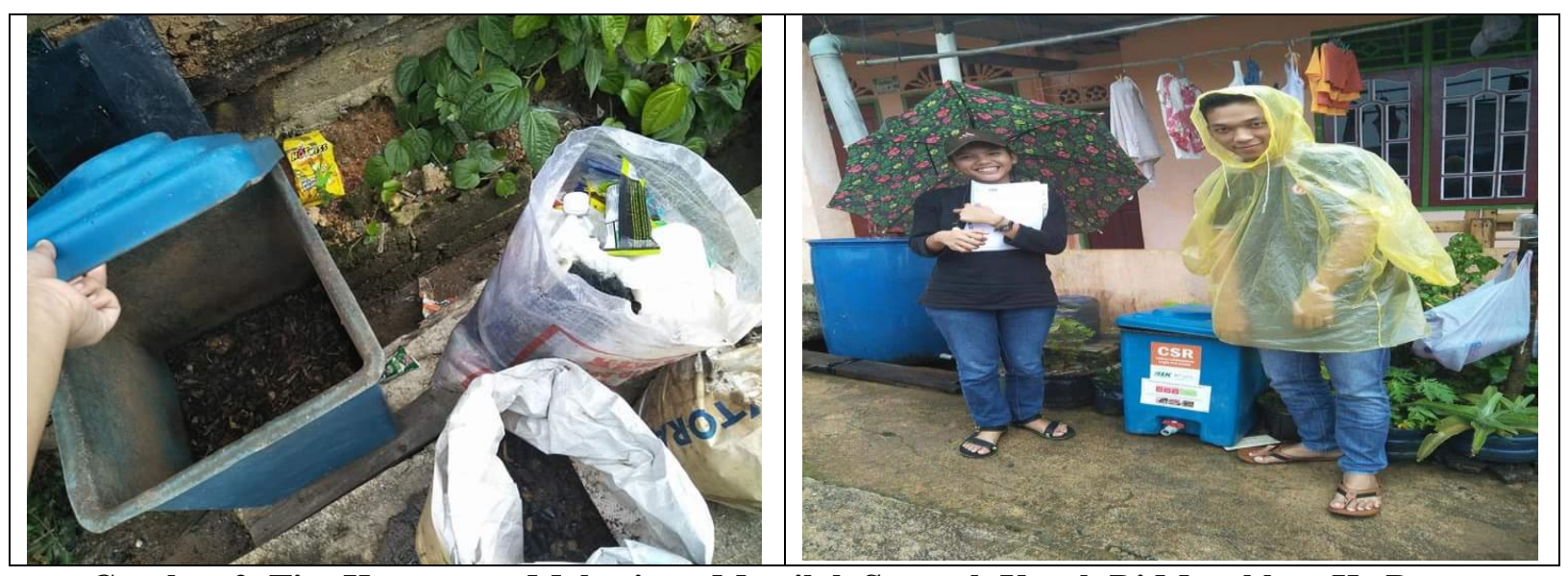

Gambar 2. Tim Komposter Mahasiswa Memilah Sampah Untuk Di Masukkan Ke Drum Kompos

Kegiatan pelatihan pemanfaatan sampah menjadi kompos yang di ikuti oleh Mahasiswa STT Real Batam sebagai wujud dari kegiatan pengabdian kepada masyarakat yang di mulai dari tanggal 24 semptember 2017 sampai dengan 30 januari 2018 di wilayah kavling Bukit Mutiara, RT 001 RW 020, Kelurahan kabil Kecamatan Nongsa, Batam. Kegiatan ini di lakukan sebagai salah satu program Batam 1000 komposter (BIK) yang bertujuan untuk pelatihan 56 KK dengan 25 komposter dalam Reduksi sampah dari sumber melalui pemilahan dan pengomposan sehingga masyarakat mengenal betul jenis sampah seperti apa yang nantinya akan masuk ke dalam kategori kompos. ${ }^{6}$

Kegiatan pelatihan pemanfaatan sampah menjadi kompos yang di ikuti oleh mahasiswa STT Real Batam Bersama ketua PKM STT REAL BATAM yang di awali dengan sambutan dari ketua RT 001/RW 020 bersama dengan para pimpinan tokoh masyarakat lainnya, setelah itu di lanjutkan dengan pemaparan singkat mengenai sampah organic dan anorganik dan bagaimana cara mengelolah dan memanfaatkan sampah menjadi kompos yang di sampaikan oleh ketua PKM STT Real Batam. Sebelum kegiatan pelatihan ini dimulai maka setiap warga masyarakat bahkan mahasiswa yang terlibat

3 Muhammad Amiruddin, Rosida P Adam, "Pelatihan Pembuatan Pupuk Kompos Dengan Memanfaatkan Sampah Rumah Tangga Di Desa Labuan,” Pengabdian Pada Masyarakat 7 (2018): hal. 77.

${ }^{4}$ Bernard Chaniago, "Hari Peduli Sampah Nasional 2016," Suara.Com (Jakarata, February 22, 2016), https://kompaspedia.kompas.id/baca/paparan-topik/hari-peduli-sampah-nasional-dan-kebijakan-pengelolaansampah-di-indonesia.

5 Jailan Sahil,dkk., "Sistem Pengelolaan Dan Upaya Penanggulangan Sampah Di Kelurahan Dufa-Dufa Kota Ternate," Jurnal Bioedukasi 4, no. 2 (2016): hal. 479.

${ }^{6}$ Yudi Setiyadi, "Mengolah Sampah Organik Menjadi Kompos,” 2014, https://ensiklo.com/2014/07/27/ mengolah-sampah-organik-menjadi-kompos/. Diakses 20 April 2021. 
di berikan pretest untuk mengukur tingkat pemahaman warga dan mahasiswa terkait materi yang di sampaikan. Dari test yang dilakukan maka ditemukan bahwa warga telah menyadari bahwa pentingnya menjaga kebersihan akan tetapi pengatahuan untuk mengelolah dan memanfaatkan sampah masih sangat minim.

Oleh sebab itu secara umum kegiatan pelatihan pemanfaatan sampah yang di lakukan oleh mahasiswa STT Real Batam Bersama dengan lemba-lembaga masyarakat yang terkait di dalamnya dapat terselenggara dengan baik dan lancar oleh karena kerjasama yang baik. Ketua Rt setempat sangat mendukung penuh kegiatan pelatihan ini. Masyarakat pun banyak membantu tim dalam mempersiapkan kegiatan selain itu. semua peserta juga aktif dan antusias selama proses kegiatan berlangsung.
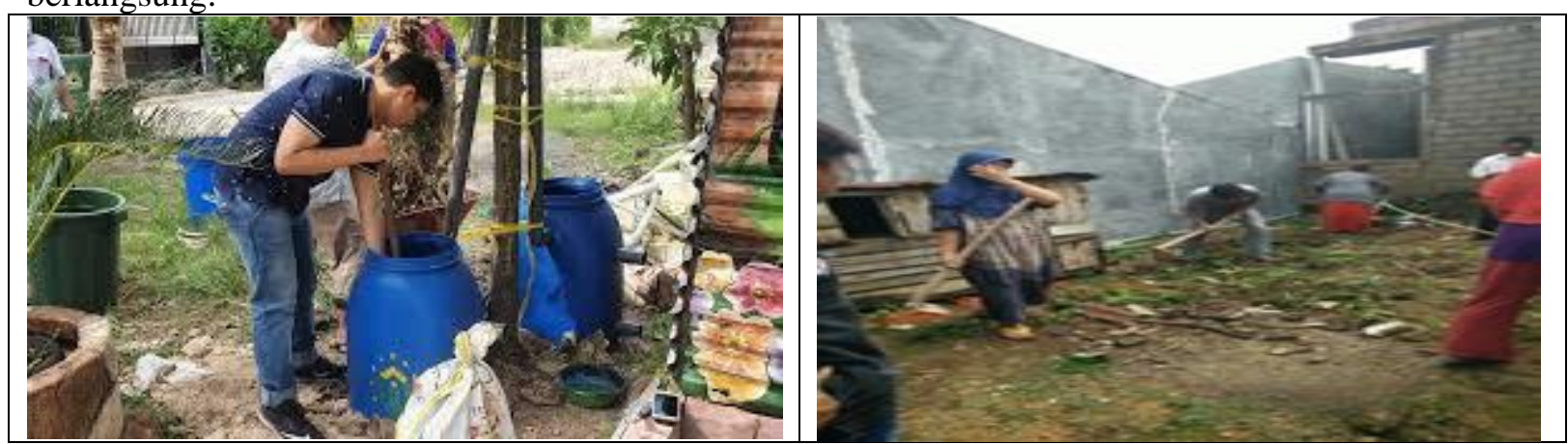

Gambar 3. Tim Komposter Mahasiswa Mengolah Sampah dan Limbah Rumah Tangga Dalam drum kompos

\section{SIMPULAN}

Dalam system pengelolaan dan pelatihan pemanfaatan sampah menjadi kompos yang dimulai dari sampah rumah tangga,lingkungan dan pasar maka hal ini di perlukan adanya prinsip-prinsip yang menaungi cara pengelolaan dan pemanfaatan sampah menjadi kompos oleh karena itu prinsip 3R sangat di perlukan karena melalui kegiatan pemilahan sampah yang merupakan solusi paradigma, yaitu solusi bagaimana paradigma tersebut dalam mengelola sampah, sehingga dari paradigma yang ada maka cara " membuang sampah" yang dalam prakteknya hanya memindahkan sampah menjadi sebuah pekerjaan yaitu mengelola sampah dalam arti di pilah untuk di manfaatkan menjadi sebuah kompos yang pada prakteknya dapat mengurangi secara signifikan timbunan sampah yang dibuang setiap harinya. problematika utama dari pada penerapan model pelatihan ini adalah bagaimana merubah pola berpikir masyarakat tentang cara membuang sampah menjadi memanfaatkan sampah. Oleh sebab itu peran dari pada RT/RW sangat di perlukan dalam hal membantu mewujudkan dan terlaksananya program Batam 1000 dalam pelatihan pemanfaatan sampah menjadi kompos yang akan menjembatani komunikasi pemerintah, mahasiswa dan masyarakat.

Setelah kegiatan pelatihan pemanfaatan sampah menjadi kompos bagi mahasiswa STT Real Batam ini terlaksana maka penulis mengharapkan bahwa ada beberapa hal yang dapat dicapai yaitu: masyarakat dan mahasiswa serta lapisan lainnya paham akan pentingnya menjaga kebersihan lingkungan sekitar, masyarakat dan mahasiswa paham akan perbedaan sampah organik dan anorganik serta di harapkan dapat memilah sampah terlebih dahulu sebelum sampah di buang pada tempatnya. Kemudian peserta dan masyarakat di harapkan juga dapat mengerti bahwa sampah organik dapat di olah menjadi pupuk kompos serta bagaimana cara mengelolahnya. Sehingga sampah organik yang awalnya terbuang begitu saja, menjadi sesuatu yang menjadi nilai tambah dan berdaya guna setelah di Kelola menjadi kompos.

\section{SARAN}

Selama proses kegiatan pelatihan berlangsung hingga selesai pada waktunya yang telah di tentukan maka di temukan beberapa permasalahan yang menghambat kegiatan tersebut dan ada beberapa harapan yang belum tercapai. Sehingga adapun saran yang untuk kedepannya mengenai kegiatan selanjutnya yaitu: di harapkan bahwa mahasiswa dapat berpartisipasi dalam mengadakan kegiatan pelatihan ini kepada mahasiswa lainnya di lingkungan sekitar kampus dan dapat sesering mungkin di adakan mengingat bahwa masih cukup banyak wilayah perumahan yang terbilang masih 
kotor dan menghasilkan sampah yang cukup banyak, kemudian di harapkan bahwa kegiatan ini dapat berkelanjutan diadakan namun fokusnya bukan hanya pada pengelolaan sampah saja menjadi kompos namun pendaur ulang sampah juga dapat di lakukan baik terkhususnya sampah anorganik. Selanjutnya di harapkan bahwa kegiatan seperti ini dapat menjadi pusat perhatian pemerintah untuk dapat dilakukan penanganan secepatnya demi menjaga kebersihan lingkungan kota batam dan menjadikan batam menjadi kota yang bersih dan sehat, sehingga masyarakat yang ada di batam juga tidak muda terserang penyakit.

\section{UCAPAN TERIMAKASIH}

Penulis mengucapkan terimakasih kepada STT Real Batam dan warga masyarakat, perangkat lurah serta tokoh masyarakat di wilayah RT 001/RW 020 kelurahan kabil, kecamatan nongsa, Batam Kepulauan Riau, dan juga kepada seluruh pihak yang memberi dukungan dan membantu pelaksaan kegiatan Pengabdian kepada masyarakat ini yaitu pelatihan pemanfaatan sampah menjadi kompos bagi mahasiswa STT Real Batam.

\section{DAFTAR PUSTAKA}

Amiruddin, Muhammad, and Rosida P Adam. "Pelatihan Pembuatan Pupuk Kompos Dengan Memanfaatkan Sampah Rumah Tangga Di Desa Labuan.” Pengabdian Pada Masyarakat 7 (2018): 77.

Bambang Yuniarto. Membangun Kesadaran Warga Negara Dalam Pelestarian Lingkungan. Yogyakarta: CV Budiman Utama, 2018.

Chaniago, Bernard. "Hari Peduli Sampah Nasional 2016.” Suara.Com. Jakarata, February 22, 2016. https://kompaspedia.kompas.id/baca/paparan-topik/hari-peduli-sampah-nasional-dan-kebijakanpengelolaan-sampah-di-indonesia.

Sahil, Jailan, Mimien Henie Irawati Al Muhdar, Fachtur Rohman, and Istamar Syamsuri. "Sistem Pengelolaan Dan Upaya Penanggulangan Sampah Di Kelurahan Dufa-Dufa Kota Ternate.” Jurnal Bioedukasi 4, no. 2 (2016): 479.

Sri Wahyuni, dkk. "Pelatihan Pengolahan Sampah Organik Skala Rumah Tangga Dengan Metode Takakura Di Desa Gebung." Indonesia Journal of Cummunity empowement 1161, no. 2657-117 (2019): 53.

Yudi Setiyadi. "Mengolah Sampah Organik Menjadi Kompos." 